\title{
Increasing the Efficiency of the Grid System using Renewable Energy
}

\author{
B. O. Anyaka, and U. O. Orji. \\ Department of Electrical Engineering University of Nigeria, Nsukka Enugu State, Nigeria.
}

\begin{abstract}
The limitation of the conventional energy supply in Nigeria has heightened the need for researches in renewable energy alternatives. This paper, therefore, proposes solar energy as an effective option with particular focus on industrial and communication sectors. A detailed investigation of the cost effectiveness and energy efficiency of the systems were undertaken. The results confirmed solar energy as a veritable option for sustainable national development.
\end{abstract}

Keywords: Solar Energy, Photovoltaic Cell, Efficiency, Grid System, industry.

\section{Introduction}

Renewable energy sources are those sources of which the occurrence is partly or wholly regenerated in the course of the annual solar cycle or the supply of which for all intents and purposes is considered unlimited or inexhaustible.[1]

Renewable electricity also refers to electric power obtained from energy sources whose utilization does not result in depiction of the earth resources.[2] Emphasis is laid on the fact that renewable energy sources do not result in consequent depletion or reduction in available earth resources. The sun is a free, abundant and inexhaustible energy resource and the basic source of all other forms of energy.[3] Renewable energy has the capacity to meet the growing energy need of the world without contributing to global warming, pollution and other environmental hazards. Potentially, the sun, wind, biomass and hydro are referred to as renewable since these resources naturally replenish themselves on periodic basis.

Statistics shows that renewable energy could meet as much as 15\% of Europe's primary energy demand by 2013.[4]

In Nigeria, renewable energy is a very important tool and presents wonderful and unique opportunities to some part of the country that will increase access to electricity services nationwide particularly in rural areas.

\section{Sources Of Renewable Energy}

In Nigeria, renewable energy sources are not out of reach. In fact, the amount of energy resources at our disposal, if properly harnessed, will drive our nation to energy independence. Here, the paper took a look at the available sources, of renewable energy, their location, intensity and methods of harnessing them. The different renewable energy resources in Nigeria are:

1) Solar Energy.

2) Wind Energy.

3) Hydro Energy.

4) Biomass.

5) Geothermal Energy.

\section{Solar Energy}

Solar energy is energy derived from sunlight. It results from continuous process of nuclear fusion where tons of hydrogen are converted into tons of helium per second and some are converted to energy as shown below.

$$
\text { . } \mathrm{H}^{+}+\mathrm{H}^{+}=\mathrm{He}^{++}+\text {Energy - - - - - - - } 1
$$

The rate at which radiant energy fails on a surface is known as irradiance. It is measured in $\mathrm{W} / \mathrm{m}^{2}$. If we integrate irradiance with respect to time, we get irradiation measured in $\mathrm{J} / \mathrm{m}^{2}$. Outside the earth is atmosphere, irradiance on the average is about $1350 \mathrm{w} / \mathrm{m}^{2}$ with variation of $\pm 3.5 \%$.[5] The earth receives about 174 petawatts of energy from the incoming solar radiation. About $30 \%$ is reflected back to the space and the rest absorbed by clouds, oceans and land mass.

In Nigeria, solar energy radiation is fairly well distributed. In the far north, we have about $7 \mathrm{kwh}$ per day of solar radiation per $\mathrm{m}^{2}$. In coastal areas it is about $5.5 \mathrm{kwh} \mathrm{m}^{-}$, for example, if solar collectors or modules were used to cover $1 \%$ of Nigeria's land about $923778 \mathrm{~km}^{2}$, it is possible to generate $485 \mathrm{Gwh}$ of solar electricity per year.[6]. Solar energy from the foregoing promises to be a reliable source for improvement in electricity supply in Nigeria's energy scenario. 


\section{The Photovoltaic Cell}

The major way of converting the solar energy from the sun into electrical energy is by the use of photovoltaic cell commonly called PV or the solar cell. After William Shockley's theory of devices formed from junctions of positive and negative region, manufacture of solar cells began. The first commercial use of the new solar cells was on spacecraft beginning in 1958.[7]

Basically, the solar cell is made of a large area semiconductor diode. By doping, that is addition of impurities to the semiconductor crystal, $\mathrm{p}-\mathrm{n}$ junction is created. If we consider silicon as the basic crystal and we add phosphorus atoms, we have five outer electrons available for bonding but only four is required.

The remaining single electron roams as free electron. In this crystal, the region where there are many negative electrons is called n-region. With Boron atom, having only three electrons, an electron is required for complete bonding. This is borrowed from another neighbouring atoms, thereby creating an 'empty space' in that atom. That space is called the hole. A region were we have majority charge carriers as holes is called the p-region.

The differences in concentration between the two region, cause electrons to diffuse into the p-region and hole into the n-region and an electrical field is set up. A space-charge region is built up until further diffusion of carriers are avoided. When light falls on the semiconductor, electron-hole pair is generate. This leads to an increase in minority carriers. These charge carriers diffuse to the contacts of the $\mathrm{n}$ and $\mathrm{p}$ sides. A tension voltage $\mathrm{v}$ is detected. The value of this voltage depends on the intensity of light. The characteristics of the solar cell without any radiation on it is same as the diode characteristics, it is alse called the dark characteristics when the solar cell is illuminated, the characteristic shift by an amount of current called the photocurrent. These characteristics are shown in figure 1.

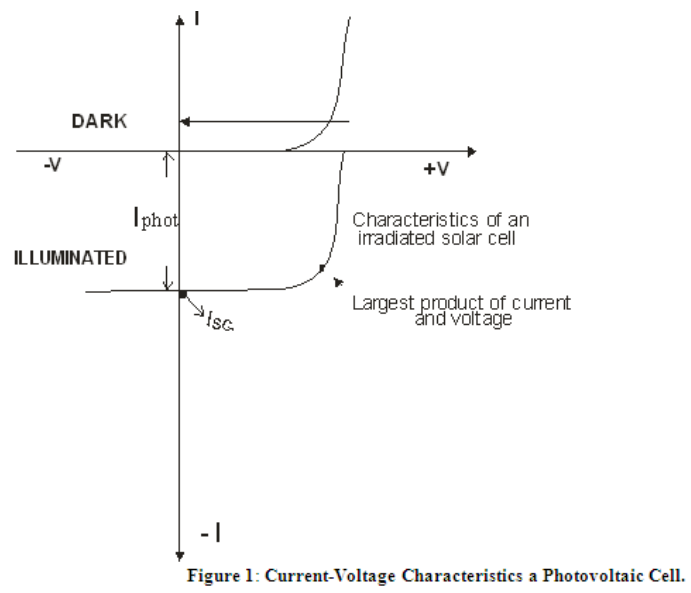

It is very important to note the two principal characteristics of the photovoltaic cell. They are the open circuit voltage and the short circuit current. The open circuit voltage is the voltage between the contacts when the cell is not supplying currewnt. This is denoted here by $\mathrm{V}_{\mathrm{oc}}$. The short circuit current occurs when the cell is shorted circuit. Thus, the, theoritically optimal power attainable is the product of the open circuit voltage and the short circuit current.

Popt $=\mathrm{I}_{\mathrm{sc}} \times \mathrm{V}_{\mathrm{oc}}$.

The maximum power a cell can produce is called the peak power $\mathrm{W}_{\mathrm{P}}$. This output is directly proportional to area of the cell. The attainable power is the greatest possible product of $\mathrm{I}$ and $\mathrm{V}$ at the operating point.

$\mathrm{P}_{\max }=\mathrm{I}_{\max } \times \mathrm{V}_{\max }$.

The ratio of $P_{\max }$ to $P_{\text {opt }}$ describes how rectangle the I-V characteristics can be, it is called FILL factor. The relationship between cell current I (A), output power (W) and cell voltage V (v) are shown below. 


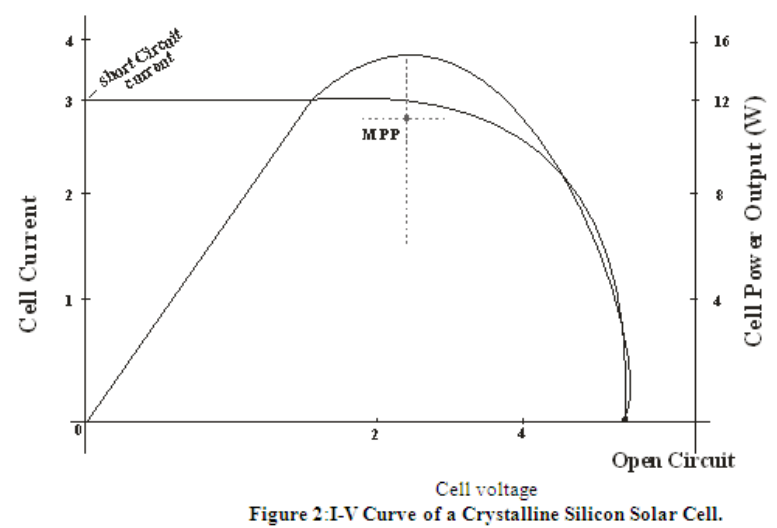

\section{Efficiency Of The Solar Cell}

This is defined as the ratio of the electrical power output to the irradiated power on a solar cell. The efficiency depends irradiance and spectrum. The conversion of efficiency solar cells is determined under standard conditions like irradiance $1 \mathrm{~kW} / \mathrm{m}_{2}$, cell temperature $25^{\circ} \mathrm{C}$,inclination angle. For crystalline silicon, it is about $28 \%$. This low conversion efficiency is caused by the following:

1. Silicon is an indirect semiconductor. Its absorption coefficient is comparatively low.

2. The band gap for silicon is about $1.1 \mathrm{eV}$. Photons with high energy transfer excess energy as heat while those with lower energy are not absorbed at all.

3. The maximum voltage, $\mathrm{V}_{\mathrm{oc}}$ depends on the difference of the potentials given by the $\mathrm{p}-\mathrm{n}$ tansition. It is about $0.7 \mathrm{~V}$ for silicon.

\section{Effect Of Temperature On Solar Cell Voltage Of Output}

With increase in temperature, efficiency decreases. The solar energy absorbed by the photovoltaic cell is converted into both thermal and electrical energy. The output of a crystalline cell dicreases approximately $0.5 \%$ for every $1{ }^{\circ} \mathrm{C}$ increase in the temperature of the cell. The implication is that at a temperature of say $30^{\circ} \mathrm{C}$ the cell output is reduced by $15 \%$. Figure 3 . illustrates the temperature effect on the I-V curve.

Currently, the efficiency of the solar cells that are commercially available vary between $5 \%$ and $17 \%$. However, more production methods are being developed to produce photovoltaic cells with high efficiencies. For instance, higher performing galluim - arsenide GaAs and galluim-antimony ( $\mathrm{GaSb}$ ) cells, composed of several layers have already achieve efficiencies of about $31 \%$.

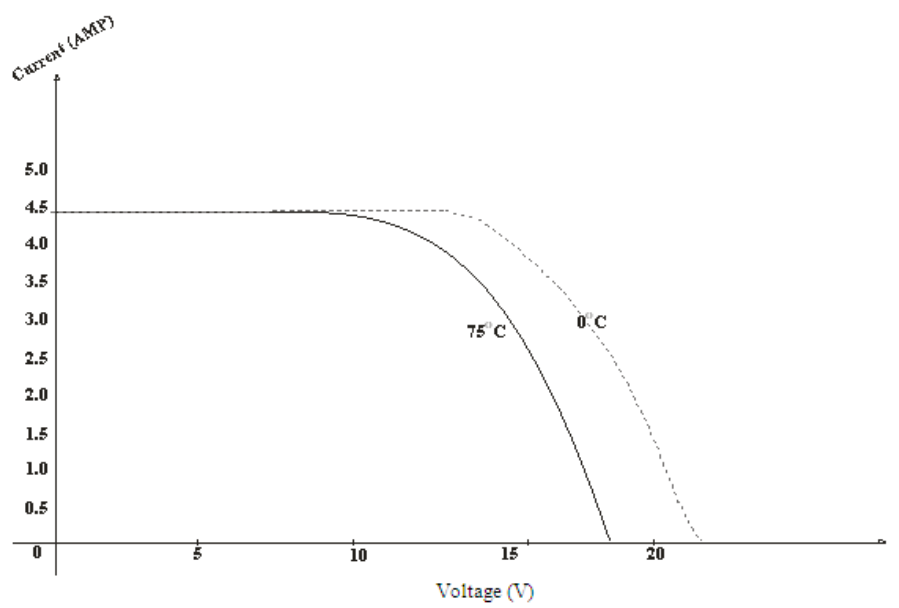

Figure 3: Effect of Temperature on the I-V Curve of a Solar Cell

\section{Types Of Photovoltaic Cells}

These are based on the type of materials used to manufacture the cells. We are going to take a close look at four types. They are:

1. Monocrystalline Silicon Cells

2. Polycrystalline Silicon cells.

3. Thin film cells.

4. A morphous silicon cells. 


\section{The Monocrystalline Silicon Cells.}

This is produced by growing crystals out of pure molten silicon. This crystal is then cut into slices between 0.2 and $0.3 \mathrm{~mm}$ thick. This is the basis of monocrystalline solar cell. The procedure for doing this is as follows:

Silicon is first melted at $1400^{\circ} \mathrm{C}$. A small silicon crystal properly cooled is used as seed to start up crystallization process. As the seed is removed gradually, the silicon solidifies at the interface between the molten form and the seed. This yields pure silicon. Impurity is added as the growth progresses. A controlled amount of impurity like boron is added to the melt in order to dope the silicon. After these processes, the silicon ingot is sliced into wafers. It is cumbersome to cut ingots, therefore a variety of methods are being investigated to grow silicon crystal directly into sheets. Once the wafers are got, the next is the cell fabrication. The fabrication process takes the following steps;

1. Surface texturing: Due to damages that occurred during sawing, etches are used to remove microns of silicon chemically.

2. P-n junction formation: Wafers are usually p-type. By thermal diffusion of $n$-type impunty, $p$ - $n$ junction is formed.

Monocrystalline silicon cells have efficiency between $11 \%$ and $16 \%$ and they require smaller areas for solar energy capture.

\section{Polycrystalline Silicon Cells}

This is sometimes called multi-crystalline cells. It is also produced from highly pure molten silicon. The difference is that here we use casting process. The procedure is as follows:

The Silicon is heated to a high temperature and cooled under controlled conditions in a mold. As the silicon sets, multi crystals form. Then, the crystals are cut in wafers. Efficiency of polycrystalline silicon cells lies between $11 \%$ and $15 \%$.

\section{Thin-Film Solar Cells}

Thin-film technologies can use silicon and non-silicon materials to produce photovoltaic cells. Examples include Copper-indum-diselenide (CIS), cadmum-telluride [CdTe), etc. the thin film solar cells have low efficiency example 6-8\% for CIS. But they have come to be highly competitive owing to the following advantages.

1. They require smaller materials and low energy during manufacture,

2. They offer high resistance to shading and high temperatures.

3. Due to (1), they promise low production cost

\section{Amorphous Silicon Cells}

Amorphous silicon cell differ from crystalline silicon in that the atoms of silicon are not located at specific distances from each other and the angle between $\mathrm{Si}$-Si bond do not have unique values.[8] Cells from this materials are used basically in watches, calculators, etc. thickness of this cell is only about 0.5-2.0. They also require small raw materials for their production than monocrystalline, efficiency lies between $6 \%$ and $8 \%$.

\section{Photovoltaic Systems}

There are quite a large number of photovoltaic systems but we will take a look at those concerned with electric power generation. They include:

1. Grid connected systems.

2. Stand alone systems.

3. Solar power satelite.

4. Concentrating solar power systems.

\section{The Grid Connected Systems}

In grid-tied systems, the DC electricity produced by the PV array is fed into the grid inverter. The inverter converts DC electricity into AC. This AC is supplied to the grid. In some cases part of the AC produced may be supplied to the building. If the array is not supplying enough electricity for the building, electricity is supplied by the grid. An export meter monitors the amount of electricity put on the grid and an import meter monitors the amount taken from it. Grid connected inverters convert DC electricity produced to single phase or three phase electricity at a particular voltage and frequency. Inverters used in grid systems are not the same as those used in stand- alone systems. They are rated in Wp, peak waltage of the PV array they are connected to. The block diagram for grid tied system is shown in figure 4 , below 


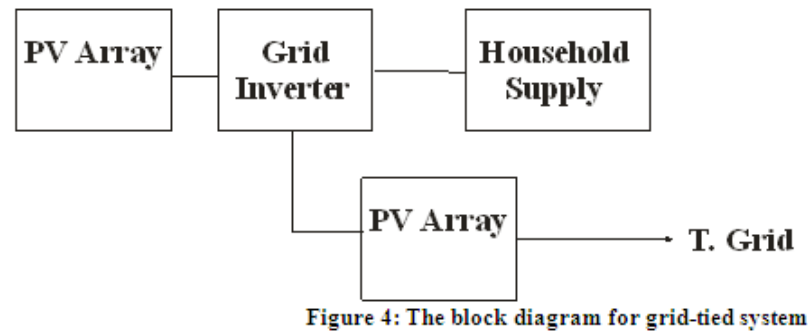

Both inverter and the solar array are meant to be compatible. In other to match the inverter to the array, the followings specifications are needed.

1. DC nominal power and peak power input.

2. DC nominal current and DC peak current input.

3. DC nominal voltage and DC peak voltage input.

4. The maximium power point voltage range.

5. Minimum power needed before inverter begins to feed the grid.

6. Stand-by power consumption.

On the Output / Grid / AC side, the following specifications are necessary.

1. AC nominal power output and $\mathrm{AC}$ peak power output.

2. AC nominal and peak output currents.

3. Inverter efficiency over a range of loads.

\section{Design Of Grid Connected Pv Systems}

We take the following into consideration during the design of grid connected systems.

1. Size of roof, its orientation and angle of inclination for roof mounted systems.

2. Freedom from shading.

3. Technical specification of the modules and inverter.

4. Client's Taste.

5. Finance.

6. Geographical location, longitude and latitude.

7. Site annual temperature range.

\section{Stand-Alone Pv Systems}

They are also known as autonomous systems or Island systems. In stand-alone systems, DC electricity is produced and sent to the battery through the solar charge controller. This DC electricity can also be used directly in places where DC appliances are used. If AC loads are available, appropriate inverters are used to convert the DC to AC. The DC may be used directly without batteries.

\section{Components Of The Stand-Alone Systems}

The basic components of PV stand-alone systems are:

The PV Modules and Arrays. The PV modules ought to produce enough electrical power to supply all the appliances in the systems. They must be configured to match the system DC voltage. This system voltage basically is determined by the battery system. The operating voltage of the PV array must be enough to charge the batteries. For instance, A $12 \mathrm{~V}$ battery requires about $14.4 \mathrm{~V}$ to charge it. This helps to take care of losses in cables, charge controllers, diodes, etc.

Another important point is the inclination of PV cells during mounting. This is the angle between the Photovoltaic cells and the earth's surface. Basically the amount of solar energy delivered at any part of the world is determined by the following:

a) Sun rays inclination at any geographical location.

b) Thickness of the atmosphere between the specific point and the sun. So, it means that at every point in the world, the solar panels must be oriented so that the energy is captured in maximum. Let the angle of inclination be $\phi z$, insolation, $\mathrm{I}$, is given by

$\mathrm{I}=\mathrm{S} \operatorname{Cos} \phi \mathrm{z}$

$\mathrm{S}=1000 \mathrm{Wm}^{2}-\ldots \ldots$

$\phi z$ depends on the following: One's location that is latitude, time of the day (hour) season of the year (declination). Their respective angles are $\phi$ (Latitude angle), $\mathrm{H}$ hour angle and $\partial$ (declination). Therefore; $\phi z=\operatorname{Cos}-1(\operatorname{Sin} \phi \operatorname{Sin} ð+\operatorname{Cos} \phi \operatorname{Cos} ð \operatorname{Cos} \mathrm{H})$. 


\section{The Charge Controllers}

The basic functions of the charge controllers are to protect the battery and ensure that it has a long working life span. Batteries can be over-charged or over-discharged. The charge controllers do the following.

1. Protect the battery from over-discharge. It does this basically using a principle called Low Voltage Disconnect (LVD). This disconnects the battery from the loads when the voltage level drops to a certain unacceptable level.

2. Protects the battery from over charging by limiting the charging voltage. The principle is called High Voltage Disconnect (HVD).

3. Prevent current flowing into the PV array at night. Charge controllers can also have other function like overload and short circuit protection, temperature compensation, lighting protection, indicators, etc. Generally, charge controllers can help increase output by $10 \%$.

\section{Batteries}

When there is insufficient solar radiation like during stormy weather, nights, etc. Batteries are needed to keep the PV system functioning. The Deep Cycle batteries are normally used because they have low self discharge rate and good charging efficiency at low charging current. When several batteries are connected the results are system is known as Battery Bank. Batteries are normally rated in voltage and Ampere-hour. For instance, we can have a battery of $12 \mathrm{vdc}, 120 \mathrm{Ah}$. This implies that the battery can deliver a current of $1 \mathrm{~A}$ in $120 \mathrm{hrs}$. It is worthy to note that the capacity of the battery is affected by the current it discharges and temperature.

Based on the current and voltage requirements, battery connected can either be in parallel or series. The connection are shown below for $24 \mathrm{~V}, 400$ A system using four $12 \mathrm{~V}, 200 \mathrm{Ah}$ batteries and 12 V 400A system using two, $12 \mathrm{~V}$ 200Ah batteries.

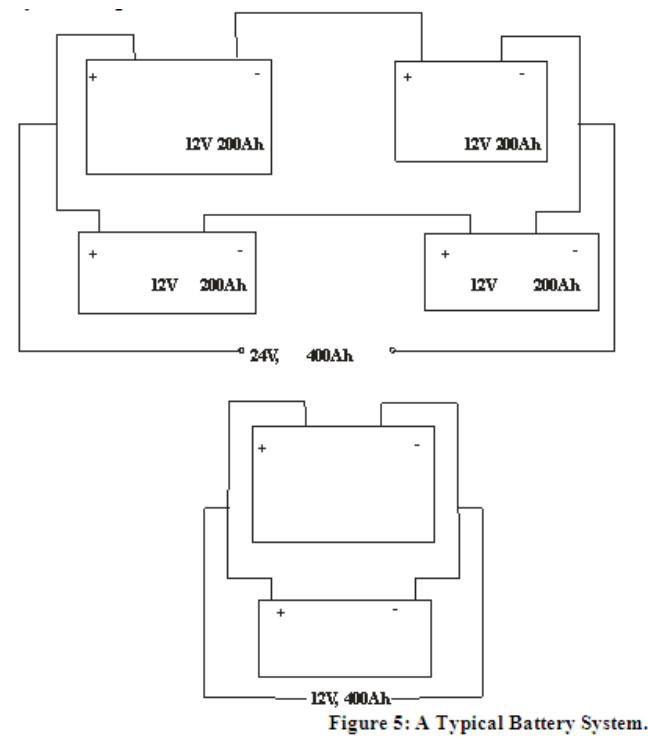

For proper maintenance of the battery system, we normally charge batter in 3 stages.

1. The Bulk Charge: At this stage, the battery is given as large a charge as possible.

2. The absorption charge: It is then charged to a constant voltage but at reduced current for complete charging process.

The Float Charge: at this point, the battery is just kept topped up. A good charge controller can ensure that these processes work properly.

\section{Renewable Energy As Alternative Source Of Energy In Nigeria}

The energy situation in Nigeria today is deplorable. The installed capacity in Nigeria is about 5981.6MW between 1990 and 2000. Only nine power situations with combined capacity of 4681MW were operational as at December 2005.[15] 
Table 1: Power Stations in Nigeria.

\begin{tabular}{|c|c|c|c|c|}
\hline S/N & Power Station & Plant Type & Capacity (Mw) & Operator \\
\hline 1. & Kanji & Hydro & 500 & Phcn \\
\hline 2. & Jebba & Hydro & 578 & Phcn \\
\hline 3. & Shiroro & Hydro & 1320 & Phcn \\
\hline 4. & Egbin & Oil/Gas & 150 & Phcn \\
\hline 5. & Sapele & Oil/Gas & 270 & Phcn \\
\hline 6 & Detta & Oil/Gas & Phcn & Aes \\
\hline 7. & Egbin Aes. & Gas & Gas & Agipjv. \\
\hline 8. & Okpai & Gas & $\mathbf{4 6 8 1}$ & Phcn \\
\hline 9. & Afam & Source & \\
\hline
\end{tabular}

Source: [16]

The power system deteriorated due to negligible funding in the 1990s. Other factors like inadequate maintenance and refurbishment, lack of system expansion, etc. contributed in no small measure the decay. In 2000 , the estimated consumption of electricity both from grid and non-grid sources was $29,945 \mathrm{Gwh}$ which is 1.96 times the total grid electricity for that year. The excess or over grid generation was found to be provided mainly through self generation especially by industry, household and services. Due to the above estimated of electricity consumption, it is obvious that demands exceeded supply. The only reasonable and immediate response is the frequent power outages. This situation has taken its toll on the economy of Nigeria, particularly making our local industries uncompetitive in the international scene.

Transmission system in Nigeria is largely inadequate. The existing one is not able to carry the increasing demand due to lack of expansion. To salvage the situation shown in the foregoing discussion, renewable resources are posed as alternative options. We will take a look at the current state of renewable energy sources and their level of deployment in Nigeria.

Solar Energy: This has proved to be a flexible option for the Nigerian energy situation. Nigeria is situated in the high solar radiation belt of the world. In rural areas where the terrain is not accessible by conventional electricity, solar energy is a ripe option for reliable energy supply as sunlight does not discriminate terrains.

Average isolation in Nigeria is about $5.5 \mathrm{kwh} / \mathrm{m}^{2}$ day. So far the level of application of solar technologies is still low. Although efforts are being made to improve on this.

Table 2. below shows the solar P-V Electrification projects in some states in Nigeria.

Table 2: Solar P-V Electrification Projects in Some States in Nigeria.

\begin{tabular}{|c|c|c|c|c|c|}
\hline $\mathbf{S} / \mathbf{N}$ & $\begin{array}{l}\text { Capacity } \\
\text { KW }_{\mathbf{P}}\end{array}$ & Location & Sponsor & Date & Remarks \\
\hline 1 & 2.85 & Okpedi, Bende L.G.A Abia State & NCERD & 2013 & 38 Modules each of $75 \mathrm{Wp}$ \\
\hline 2. & 5.0 & Laye Ondo State & NCERD & 2013 & 160 PV Modules of 50Wp each. \\
\hline 3. & 1.5 & Usman Dan Fodio University, Sokoto & SERC/UDU & 2013 & PV Modules for IT Equipment \\
\hline 4. & 2.5 & Nassarawa State & ECN-SERC & 2013 & PV Systems for Rural Clinic \\
\hline 5. & 7.2 & Usman Dan Fodio University, Sokoto & & 2012 & 206 PV Modules 33Wp each \\
\hline 6. & 2.0 & $\begin{array}{l}\text { Ibeakpu Awka in Igboeze South L.G.A, } \\
\text { Enugu State }\end{array}$ & NERC & 2012 & $\begin{array}{lll}\text { PV Modules } & \text { for } & \text { village } \\
\text { electrification } & & \end{array}$ \\
\hline 7. & 2.0 & U. D. U. & SERC & 2012 & $\begin{array}{l}\text { PV Modules for powering IT } \\
\text { Equipment on the main campus }\end{array}$ \\
\hline 8. & 5.0 & Kawo in Kaduna State & SERC & 2013 & PV System school for deaf children. \\
\hline 9. & 4.5 & SERC, Sokoto & SERC/ECN & 2013 & $\begin{array}{l}\text { PV System for powering laboratory } \\
\text { blocks. }\end{array}$ \\
\hline 10. & 0.7 & NCERD & NCERD & 2010 & $\begin{array}{l}\text { For powering lights and office } \\
\text { equipment. }\end{array}$ \\
\hline 11. & 0.30 & NCERD & NCERD & 2011 & For powering security lights \\
\hline 12. & 0.3 & SERC & SERC/UDU & 2012 & For powering security light. \\
\hline 13. & - & NITEL & Nationwide & 2000 & Powering repeater stations. \\
\hline 14. & 0.3 & Yenogoa & - & 2012 & Street lighting. \\
\hline 15. & 2.0 & Jigawa & - & 2013 & Village electrification \\
\hline 16. & 2.5 & Govt., Gifted School, Abuja & SERC/ETF & 2003 & For powering Diginet Laboratory \\
\hline 17. & 2.5 & Govt. Girls College, Dala Kano & SERC/ETF & 2013 & For powering Diginet Laboratory \\
\hline 18. & 2.5 & Govt. Technical College, Kano & SERC/ETF & 2013 & For powering Diginet Laboratory \\
\hline 19 & 2.5 & Govt. Sec. School, Kano & SERC/ETF & 2013 & For powering Diginet Laboratory \\
\hline 20. & 2.5 & Govt. Sec. School, Tarauni & SERC/ETF & 2013 & For powering Diginet Laboratory \\
\hline 21. & 2.5 & Rumfa, College Kano & SERC/ETF & 2013 & For powering Diginet Laboratory \\
\hline 22. & 2.5 & College of Islamic Studio Minna, Niger & SERC/ETF & 2013 & For powering Diginet Laboratory \\
\hline 23. & 2.5 & $\begin{array}{l}\text { Gboluyi Grammar School, Ile Oliyi, } \\
\text { Ondo }\end{array}$ & SERC/ETF & 2013 & For Powering Diginet Laboratory \\
\hline 24. & 2.5 & Lorreto Special School, Akin Cross & SERC/ETF & 2013 & For Powering Diginet Laboratory \\
\hline
\end{tabular}


Increasing the Efficiency of the Grid System using Renewable Energy

\begin{tabular}{|l|l|l|l|l|l|}
\hline & \multicolumn{1}{|l|}{} & & & \\
\hline 25. & 2.5 & Giver State & SERC/ETF & 2013 & For Powering Diginet Laboratory \\
\hline 26. & 12.5 & $\begin{array}{l}\text { For 5 schools scattered all over the } \\
\text { federation }\end{array}$ & SERC/ETF & 2013 & $\begin{array}{l}\text { For electrification Diginet } \\
\text { Laboratory }\end{array}$ \\
\hline
\end{tabular}

Source [17]

\section{Conclusion}

From the analysis, it is obvious that the operational cost of running the selected systems with solar systems is lower. The following points can be brought out from the analysis.

1. Although the initial cost of solar system is still high, conventional system are not cheap either. Again, current product prices of solar systems components are experiencing a downtrend since competition is now high.

2. Conventional system has lower lifespan when compared to solar systems. A $280 \mathrm{~W}$ panel designed by Yingli Solar can last for about 25 years under standard conditions.

3. Solar systems enjoy a zero running cost as no fuel is required for their daily operations. But conventional energy systems require fuel constantly.

4. Solar systems are environment friendly and even enhance beauty and aesthetic where they are used. On the other hand, conventional energy sources cause environmental pollution.

5. From table 2 above, $73.65 \mathrm{KW}$ of the solar energy can be injected into the National grid to increase the efficiency.

\section{Recommendations}

1. Government should provide incentives and subsidies to enhance accessibility of solar products to the average Nigerian.

2. The use of conventional electric generators should be de-emphasized.

3. The PHCN should incorporate solar generators in its energy generation mix. This can take the form of distributed generation.

\section{References}

[1]. Osakwe E. N. C., Energy revolution for Africa: Perspectives, prospects and issues in Nigeria, in solar and renewable Energy Company (Nig.) Ltd, meeting R and D challenge, Ucheakonam Foundation Nigeria Limited,Abuja, 2009, p.55.

[2]. Akuru U. B., Alternative means of energy sector investment in Nigeria, in solar and Renewable Energy Company (Nig) Limited meeting R and D Commercialization challenge, Ucheakonam Foundation Nigeria Limited,Abuja, 2009, p. 184.

[3]. Bala E. J. Overview of the potential of renewable energy and energy efficiency, market development and incentives in Nigeria, a paper presented at the workshop on strengthening Advocacy for use of alternatives sources of energy for sustainable development by women in leadership position, $27^{\text {th }}-28^{\text {th }}$, October 2009 UDU Sokoto, p. 19.

[4]. Juliet D and Mike B., The European Renewable Energy study the world Directory of Renewable Energy Supplies and Services, James and James Limited,UK 1996, p.31.

[5]. Taylor R. H. Alternative Energy sources for centralized generation of electricity, Adam Hilger Limited, Bristol, 1983 , p.49.

[6]. Sambo A. S., Strategic Developments in Renewable Energy in Nigeria, International Association for Energy Economics. Abuja Nigeria.

[7]. Stefan K., Solar Electric Power Generation, Photovoltaic Energy System, Spinger Berlin Heidelberg, New York, 2006 p.20.

[8]. Faulk A. Dürschner C., Remmers K., Photovoltaics for Professionals, Solar electric systems, marketing, design and installations, solar praxis AG, Berlin, 2007, p.37.

[9]. German Solar Energy Society, Planning and Installing Solar Thermal Systems for installers, architects and engineers, James and James Limited, UK, 2009, p.153.

[10]. Asphinol R., Profiting from clean energy, John Wiley and Sons, New Jersey, 2008, p.182.

[11]. Klass D. L. Ernest G. H, Fuels from Biomass and Wastes, Ann Arbor Science, 1981, p.1.Lagos Nigeria.

[12]. Okoro, M. C., The Small Hydropower Development of NESCO as a model of a successful and sustainable Development in Nigeria: UNIDO Regional Centre for Small Hydropower in Africa, Abuja, Nigeria 2006, p.26.

[13]. Jiandong T., Mini Hydropower, John Wiley and Sons Limited,UK. 1996. P. 17.

[14]. Clean Energy Ideas, www.clean-energy-ideas.com/geothermalpower.html.

[15]. Nigeria's Electricity Sector, A Review of Structure and Performance, Nigeria's Executive report, 2006, p.16

[16]. Power stations in Nigeria and Plant types.PHCN2005.Executive report,2005,p.17.Abuja

[17]. Energy Commission of Nigeria.Executive report publication 2012.p.12 Abuja. 